\title{
Improving the Competence of Diagrammatic and Argumentative Representation in Physics through Android-based Mobile Learning Application
}

\author{
Nina Liliarti \\ Universitas Negeri Yogyakarta, Indonesia, nina.liliarti1@gmail.com \\ Heru Kuswanto \\ Universitas Negeri Yogyakarta, Indonesia, herukus61@uny.ac.id
}

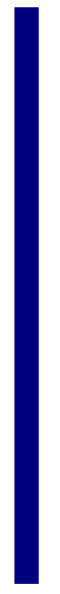

The research aimed to produce an Android-based earning media with local cultural content in the form of the othok-othok toy ship to improve the competence of diagrammatic and argumentative representation in Physics. 4D methods were used with a control and an experimental class in the first grade of a Senior High School. The learning media development began with aprior analysis, followed by an initial product design, judgment by experts and practitioners, and finally the restricted, and field testing.The media feasibility instrument was validated by experts and physics teachers. A test instrument of an essay-type was first validated by experts and an empirical test to 100 other students participating as test takers on condition that they had already studied the material. The data collection technique was through tests, N-Gain and MANOVA were used to analyse data. The research results indicated that the Android-based learning media with local content in the form of the othok-othok toy ship are able to improve the competence of diagrammatic and argumentative representation in physics learning. The media is applicable to use as physics learning media both inside and outside the classroom.

Keywords: learning media, Android, local culture, diagrammatic representation, argumentative representation

\section{INTRODUCTION}

Designing a curriculum by utilizing local wisdom and technology could build new knowledge(Squire, MaKinster, Barnett, Luehmann \&Barab,2013). It would bring about education with the school, with knowledge, and with local wisdom as the basis (Mungmachon, 2012). Local knowledge as the basis could improve the cultural values in society and maintain the cultural durability in the on going era of globalization (Saputra, 2013). Skills of the $21^{\text {st }}$ century and the use of technology are necessary for the harmonization and adaptation of one's learning knowledge with the times in order to be able to operate in times of change (Keane, 2014). The incorporation of cultural

Citation: Liliarti, N, \& Kuswanto, H. (2018) Improving the Competence of Diagrammatic and Argumentative Representation in Physics through Android-based Mobile Learning Application. International Journal of Instruction, 11(3), 106-122. https://doi.org/10.12973/iji.2018.1138a 
knowledge into the school curriculum is useful in maintaining citizens' identity in a nation (Baynes \& Austin, 2012).

The use of innovative technology in education provides educators with a valuable opportunity for making improvement in the curriculum in order to make it an interactive one which is more inclusive and interesting (Thomas, 2013). By means of the technological application, users of devices with Windows and Android would be able to explore concepts of physics wherever they are.

The use of the Android device is already quite widespread (Abildinova, Alzhanov, Ospanova, Taybaldieva,Baigojanova, \& Pashovkin,2016). It goes along with the use of mobile devices, are the most common. which keep growing in popularity into consumers' gadgets that are among those, mobile devices are the most common (Liu, Horton, Lee, Kang, Rosenblum, O'Hair, \& Lu, 2015). Data from Stat Counter Global Stats in 2017 indicates an increasing use of Smart phoneon monthly basis through an operating system called Android. The most recent data are those in February which indicates an increase of $37.47 \%$. The hardware platform provided by that system is so convenient for developers to use that they need not spend much effort in materializing their ideas. It enables Android to have further developments (Leetian, 2013; Wang, Gu, $\&$ Ma, 2014). Technological progress enables interactive learning, and Smartphone would have a chance to be developed into media that supports the learning conducted in schools.

Indeed progress in technology gives more chances for education to conduct interactive learning. Android enables its users to communicate with others wherever they are without any hindrance (Hanafi \& Samsul, 2015), and it accordingly explains how the Android operation system provides an efficient learning in which the learners could download the learning materialsanytime anywhere (Jengathe, Dinesh, \& Rojatkar, 2015). Thus ,Smartphone users would enjoy physics learning (Wong, \& Chau, 2011).

Difficulty in learning physics is caused, among others, by the various simultaneous different matters inherent in the presentation of a lesson in physics. The matters are practicum sessions, formulas and calculations, graphs, diagrams/pictures, and concepts. As stated by Ornek, Robinson, \& Haugan(2008),learners regard that physics as a school subject affects their comprehension and learning. Competence in problem solving is a main part of physics learning (Docktor, Jennifer, \& Mestre, 2014)

Here, the context is the important of connection that made between physics learning and the local culture around the learners, and also the service of mobile telephone application technology in the learning. The objective of the research was to determine the benefits of an Android-assisted learning media with local culture as basis in physics learning.

\section{LITERATURE REVIEW}

\section{Local Culture as Learning Resource}

Traditionally, education is already offered in the classroom where students could directly interact with their teachers and that is the type of interaction that makes 
students' physical presence very important. However, the wide distribution of information that easily enabled by means of the computer and communication technology has made the learning process easier to accomplish. Local wisdom is part of culture, moreover, local culture is an element of traditional culture that is deeply rooted in human life and in society, and then, the element is related to the human resources, cultural sources, economic matters, security, and law in the region concerned (Geertz, 1973).

Education integrated with local culture could be accepted as scientific knowledge (Parmin, et al., 2016). According to research by Azizah et al.,(2015), the use of a device for physics learning at SMA (Sekolah Menengah Atasor 'senior high school', the second level of the two-level high school system)with materials concerning fluid dynamics and the local culture in Riau as basis, developed by using the 4D model(with stages referred to as define, design, develop, and disseminate),indicated success in improving learners' cognitive competence.

Research by Ardan, et al., (2015) proves that the local wisdom in a region is able to use in teaching learning. It is able to support the program of the preservation of local wisdom in order that it is not undesirably changed by time. Therefore, by integrating local culture, knowledge and cultural values, it may deliver to students as contextual learning. In the research result, the students do not abandon the local culture that possessed by the regional inhabitants.

The children's toy in the particular research is othok - othok. It was popular in the era of the 80s (Choiriyah, 2015). It comes in two sizes. The small-sized ship is $15 \mathrm{~cm}$ long and $6 \mathrm{~cm}$ wide and the large-sized ship is $20 \mathrm{~cm}$ long and $8 \mathrm{~cm}$ wide. The othok-othoktoy ship comes with many different colour choices. Each othok-othok basically consists of thetoy ship hull, apipe to fill water into a kettle, and a container with cotton for flame making to produce heat that boils the water. The toy is called the othok - othokship because in operation it emits a repetitive knocking sound (something like “Tok.Tok.Tok.Tok.Tok.”).

Physics have two characteristics.First, physics is a mathematical description of natural phenomena and, secondly, it is also a prediction of concerned natural phenomena which is concluded from measurement and observation results (Holbrow, Lioyd, \& Amanto, 2010). Thus, physics learning becomes a process of improvement in the learners' selfpotential through the study of natural phenomena.

\section{M-Learning as Part of Learning Media}

Since the arrival of the cellular telephone in1980 (Huet, \& Tcheng, 2010),mobile devices have made possible the occurrence of new creativity (such as that in the activity of music video designing), new work performance, and new ways for accessingonline sites. Mobile devices have quite a high selling power and this gives the impression that technology supports education (Ally, 2009). The success and the integrative value of technology depends greatly on the teaching and learning process itself (Kayalar, 2016). Mobile learning helps the user to interact more (Maha \& Heba, 2015). 
Sarrab, Elgamel,\& Aldabbas (2012) mention a technique of conducting m-learning by using wireless and mobile technology in improving learning and education in general. Mobile devices could also play an active rolein the teaching and learning (Gonzalez, da Silva, Canedo, Huete, Esteban, Manso, Rochadel,\& Gonzalez,2015) of Physics.

The use of Smartphone is usually accompanied with the use of Android applications (Android refers to the name of an operation system). The use of the Android-based learning media is one of the applications of the $21^{\text {st }}$-century learning style (Calimag, Mugel, Conde, \&Aquino, 2014). Meister (2011) and Yektyastuti, and Ikhsan, (2016)mentions that a smartphone, could be used to support the learning process with careful attention paid to reviews done to such device serving asa learning media. Research by Chang, Chen, and Hsu (2011) indicates that learning materials packaged in digital game form influence the learning process and also that the learning media in digital game form could improve learners' learning achievement.

Android mobile devices have superiority with their $24.6 \%$ in sales in comparison with Windows mobile devices with their 9.8\% in sales in 2014 (Gandhewar \& Sheikh, 2010). Android devices, whose initial function was merely as means of entertainment, are now developing into a learning media that could help students in learning (Ma, Gu,\& Wang, 2014).

\section{Competence in Diagrammatic and Argumentative Representation}

Problem solving is described as an exploration using representation (Docktor \& Mestre, 2014). Representation could become a competence factor in relation with conceptual understanding and scientific reasoning (Nieminen, Savinainen, \& Viiri, 2012). McBride and Cooper (2016) support the idea that definition and representation are processes that state the scope and direction of a problem and organize the knowledge required for problem solving.In educational psychology, representation means the modeling of concrete matters in the real world into abstract concepts or symbols (Hwang, Chen, Dung, \&Yang, 2007).

Physicists usually undertake what is called diagrammatic representation (Raghavan \& Glaser, 1995) in order to know learners' feedback (Roselli, Howard, \& Brophy, 2006). When solving a problem, learners use internal and external representation. Students who could make a diagrammatic representation generally have better competence in problem solving (Edens \& Potter, 2008). The reason is that diagrammatic representation could lessen the complexity of authentic representation and process management in problem solving (Aviani, Erceg, \& Mesci, 2015). Furthermore, argumentation, or argumentative representation,is useful as efficient mediator of task-switching performance,especially in making connections among the resulting answers available (Saeki, Saito, \& Kawaguchi, 2006), and it could be successfully used to teach declarative knowledge (Schworm \& Renkl, 2007).

\section{METHOD}

\section{Experimental design}

The research was quantitative in approach. Research and Development (R\&D) was used as method of the research.This research followed the four steps of Thiagarajan, Semmel, 
and Semmel (1974), i.e. Define, Design, Developand Disseminate. The results of need analysis, literature, and field study were drawn upon to develop materials,methods, and instruments test.

Define stage is a stage of need analysis of learning that based on the student development, learning environment, and curriculum. In this stage, it conducted preliminary analysis, students' analysis, concept analysis, and portfolio analysis. Design stage is a makinh scenario of learning media on othok-othok ship-based; Newton law, Archimedes law, and convection of heat. Develop stage aim to produce a learning media based on local value and portfolio instruments-it seems like common learning media. The difference of the developed media is not in a printed media but application for Android-smartphone.Learning media is developed through Adobe flash software. In this stage, it conducted compiling analysis of story board, lay out design, and all this thing was managed in interesting way. The measuring ability of diagram representation and argument conducted before and after the learning that aimed to know the difference of learning in experiment and control class. The developed learning media is feasible after it able to improve the ability of diagram representation and argumentation.

\section{Participants}

The research subjects were SMA students. By means of probability sampling, 60 students at the SMA were selected and divided into two groups; first half as an experimental class and the second half as a control class. The media feasibility testing involved 30 students of Grade X (the official term for the first grade of SMA), whom were yet to be given any lesson about Newton's law. The research was conducted at a SeniorState High School known as the SMA N 3, Yogyakarta, from January to May 2017.

\section{Instruments}

The research instruments went through an evaluation process by the experts and physics teachers. The instrumentswere evaluated in thematerial and media aspects of the learning media. Another aspect tested is its feasibility.A limited trial of the instrument was performed involving200 respondents to obtain empirical validity and test reliability. Data were analyzed using the QUEST software. The results showed that all test items have INFIT MNSQ between 0.76 to 1.33 which means the test item was valid and the reliability of the test item is 0.78 which means that all the tested items are reliable.

\section{Data Analysis}

The obtained data through the research instrument was analyzed through SPSS 16.0. Firstly, it needed to make sure that the data were distributed normally and homogenously. By using mean scores, gain scores were calculated. Furthermore, MANOVA was used to determine the difference in response between the two classes.

The descriptive data that was obtained from the raters were firstly used to determine the validity and reliability of the research instrument. To ensure validity, the research instrument was assessed using $\mathrm{V}$ 'aiken equation. Analysis of the validity of the research instrument, was calculated by calculating the scores of each aspects of assessment using the formula of: 
where:

$$
V=\frac{2 s}{[n(c-1)]}(1)
$$

$s=r-l_{0}$

$l_{0}=$ lowest evaluation score of validity (namely, 1 , in this case),

$c=$ highest evaluation score of validity (namely, 5 , in this case), and

$r=$ score given by the rater.

Next, the reliability of the instrument for evaluating the developed product wasdetermined by using Cohen's kappa analysis, with the criterion that a good instrument would havea coefficientreliability greater than or equal to $75 \%$.

The analysis of the learning device product's feasibility was done by calculating the mean score for each aspectusing the formulabelow:

$$
\bar{X}=\frac{2 X}{n}(2)
$$

where

$\bar{X} \quad=$ total mean score,

$\Sigma X=$ total item score, and

$n \quad=$ total number of items.

MANOVA was used to determine the difference in response between the two classes.

The research used thepretest-posttest control group designas shownin Table 1 (Wiersma \&Jurs, 2009: 146)

Table1

Pretest-Posttest Control Group Design

\begin{tabular}{cccc}
\hline No. $\quad$ Class & Pretest & Treatment & Posttest \\
\hline 1. Experimental & $\mathrm{O}_{1}$ & $\mathrm{X}_{1}$ & $\mathrm{O}_{2}$ \\
2. Control & $\mathrm{O}_{1}$ & $\mathrm{X}_{2}$ & $\mathrm{O}_{2}$ \\
\hline
\end{tabular}

Where,

$\mathrm{O}_{1}=$ Pretest,

$\mathrm{O}_{2}=$ Posttest,

$\mathrm{X}_{1}=$ using the Android-assisted learning media, and

$\mathrm{X}_{2}=$ not using the Android-assisted learning media.

The product was applied on the experimental class and the result was compared to the control class, which learned the same thing without usingthe Android-assisted learning media with local culture.

The data obtained from the pretest and posttest were analysed descriptively and quantitatively. Any increase in the learning achieved by the two classes was determined by calculating the gain score of each student who had taken the tests.The mean gain 
score of the experimental class was also compared with that of the control class. The developed evaluation rubric was evaluated by two experts, whose evaluations indicated that it was valid and reliable.

\section{FINDINGS AND DISCUSSION}

Based on the analysis of the diagrammatic and argumentative representation as variables, the developed learning media took an Android application, in which there were learning materials related to Newton's law, Archimedes' principle, and convective heat transfer. The materials that were used during the experimentation was about Newton's law. The design of the learning media is presented in Table 2.

Table 2

Matrixof the Learning Media

\begin{tabular}{|c|c|c|c|c|c|}
\hline \multirow[t]{3}{*}{ Indicator } & \multicolumn{5}{|c|}{ Material } \\
\hline & \multicolumn{3}{|c|}{ Newton } & Archimedes & Heat Transfer \\
\hline & Newton's Law I & Newton's Law II & Newton's Law III & Archimedes' Law & Convection \\
\hline \multirow[t]{2}{*}{$\begin{array}{l}\text { Giving factual } \\
\text { content }\end{array}$} & $\begin{array}{l}\text { Presented with a } \\
\text { video of an othok- } \\
\text { othok toy ship, } \\
\text { students are asked } \\
\text { to build the factual } \\
\text { fact. }\end{array}$ & $\begin{array}{l}\text { A video of an } \\
\text { othok-othoktoy } \\
\text { ship and an } \\
\text { electric fan are } \\
\text { presented }\end{array}$ & $\begin{array}{l}\text { The concept of the } \\
\text { othok-othok toy } \\
\text { shipis being able to } \\
\text { move }\end{array}$ & $\begin{array}{l}\text { Providesan } \\
\text { animation ofa } \\
\text { floating } \text { othok- } \\
\text { othoktoy ship, } \\
\text { students are asked to } \\
\text { build the factual fact. }\end{array}$ & $\begin{array}{l}\text { The concept of } \\
\text { when the water in } \\
\text { the tubestarts to be } \\
\text { heated }\end{array}$ \\
\hline & $\begin{array}{l}\text { Factsrelated to the } \\
\text { concepts of } \\
\text { Newton's } 1^{\text {st }} \text { lawin } \\
\text { theothok-othok toy } \\
\text { ship }\end{array}$ & $\begin{array}{l}\text { Facts related tothe } \\
\text { concepts of } \\
\text { Newton's } 2^{\text {nd }} \text { law } \\
\text { inthe } \text { othok-othok } \\
\text { toy ship }\end{array}$ & $\begin{array}{l}\text { Factsrelated to the } \\
\text { concepts of } \\
\text { Newton's } 3^{\text {rd }} \text { law in } \\
\text { the othok-othoktoy } \\
\text { ship }\end{array}$ & $\begin{array}{l}\text { The application of } \\
\text { Achimedes' law } \\
\text { intheothok-othok toy } \\
\text { ship }\end{array}$ & Factof convection \\
\hline $\begin{array}{l}\text { Building an } \\
\text { argument of a } \\
\text { physical } \\
\text { phenomenon }\end{array}$ & $\begin{array}{l}\text { Built the students' } \\
\text { arguments by a } \\
\text { picture of anothok- } \\
\text { othok toy ship. }\end{array}$ & $\begin{array}{l}\text { Built the students' } \\
\text { opinion by a video } \\
\text { of anothok- } \\
\text { othoktoy ship and } \\
\text { an electric fan } \\
\text { being presented }\end{array}$ & $\begin{array}{l}\text { Built the students' } \\
\text { opinion by an } \\
\text { animation presented } \\
\text { to them ofanothok- } \\
\text { othok toy ship } \\
\text { moving due to wind } \\
\text { presence }\end{array}$ & $\begin{array}{l}\text { Built the students' } \\
\text { opinion by } \\
\text { presentedan } \\
\text { animation to them of } \\
\text { anothok-othoktoy } \\
\text { ship's condition } \\
\text { when inliquid matter }\end{array}$ & $\begin{array}{l}\text { Built the students' } \\
\text { opinion by } \\
\text { presented a video } \\
\text { to them of the } 1^{\text {st }} \\
\text { cycle of the fire } \\
\text { setting in anothok- } \\
\text { othoktoy shipand } \\
\text { the ship is moving }\end{array}$ \\
\hline $\begin{array}{l}\text { Making a diagram } \\
\text { before calculation }\end{array}$ & & $\begin{array}{l}\text { Describingthe } \\
\text { relation between } \\
\text { force and } \\
\text { acceleration }\end{array}$ & & & \\
\hline $\begin{array}{l}\text { Inserting a diagram } \\
\text { into the appropriate } \\
\text { problem solving } \\
\text { task }\end{array}$ & & & & & $\begin{array}{l}\text { The heat cycle in } \\
\text { anothok-othoktoy } \\
\text { ship }\end{array}$ \\
\hline $\begin{array}{l}\text { Giving a diagram } \\
\text { and building an } \\
\text { argumentation }\end{array}$ & $\begin{array}{l}\text { Explain the related } \\
\text { aspects of anothok- } \\
\text { othok toy ship }\end{array}$ & & $\begin{array}{l}\text { Built the perception } \\
\text { by means of an } \\
\text { animation of an } \\
\text { othok-othok toy ship }\end{array}$ & $\begin{array}{l}\text { ExplainArchimedes' } \\
\text { law through anothok- } \\
\text { othoktoy ship }\end{array}$ & $\begin{array}{l}\text { Explaintheidea of } \\
\text { heat transfer in } \\
\text { convection }\end{array}$ \\
\hline
\end{tabular}

The learning media concerned was virtual in form and could be operated in an Androidbased mobile telephone. The software program that was used to make the physics learning media was Adobe Flash Professional CS 6 with the use of Action Script 3.7. 


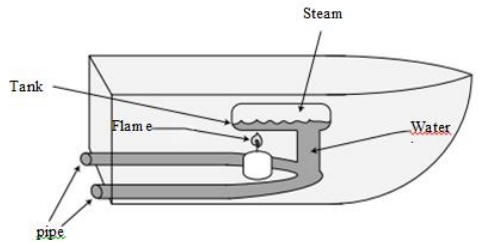

Figure 1. a

The part of othok-othok toy ship

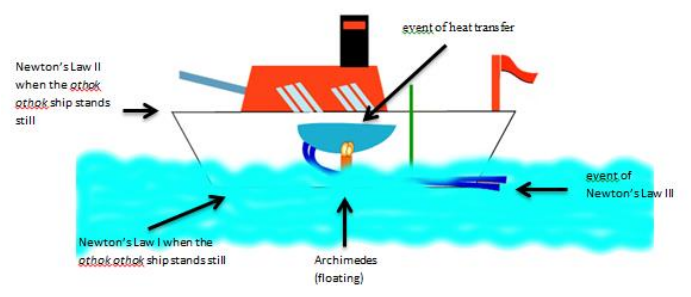

Figure 1. b.

Physical conceptscontained inOthok-Othoktoy Ship

The othok - othok toy ship (Figure 1.a.) is often seen in the Sekaten, an annual traditional festive event in Yogyakarta,Indonesia. It comes in two sizes:the small-sized ship is $15 \mathrm{~cm}$ long and $6 \mathrm{~cm}$ wide and the large-sized ship is $20 \mathrm{~cm}$ long and $8 \mathrm{~cm}$ wide, and in a variety of colours. Othok-othok toy parts are ship hull, awater-filling pipe, and a fire-making container with some pieces of cotton.

The components of an othok - othoktoy ship is presented in Figure 1. b.They are a pair of small pipes, a tank for water heaterso that evaporation occurs, and a fuse and some cotton applied with oil. The materials and tools for making an othok-othok toy ship are, among others, a sheet of tin, scissors that could cut sheet metal ,a piece of cotton, a marker,iron paint, and a paintbrush. It is called othok - othok due to the continuous repetitive knocking sound that it emits ("Tok,Tok,Tok,Tok,Tok") when it is in operation.

In the toy ship, there is some principles of physics at work, as presented in Figure 2. The principle of how the othok - othok toy ship works is based on the concept of Newton's law, Archimedes' principle, and convection heat transfer so that it could be made part of a physics learning media.

All the designed components were processed using Adobe Flash Professional CS 6 with Action Script 3.The initial page appearances from the media developmental stage are presented in Figures 3.a. and b.

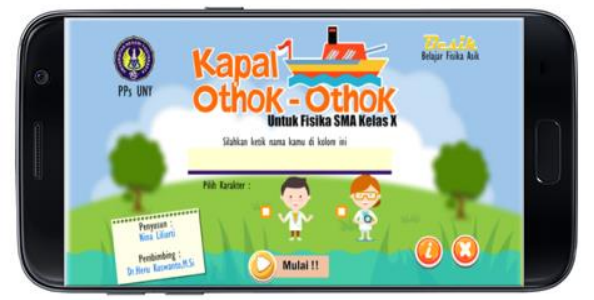

Figure 3. a.

Initial Page Appearance of the Learning Media

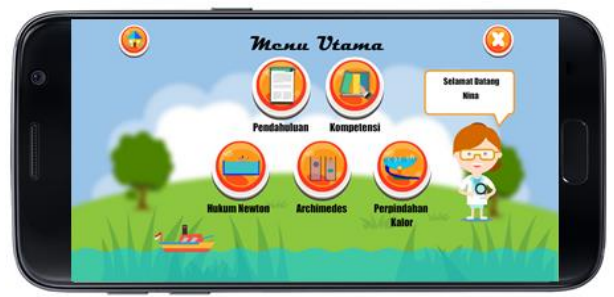

Figure 3. b.

Menu Page 
Illustrations of the learning media that showed diagrams and argumentation are presented in Figures 4. a. and b. in the form of an animation in the learning media that could improve competence in diagrammatic and argumentative representation.

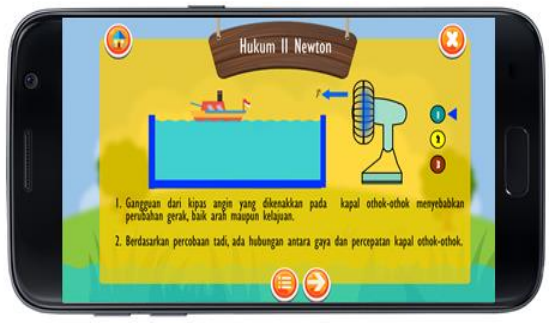

Figure 4. a.

Page Appearance of Newton's Law Animation

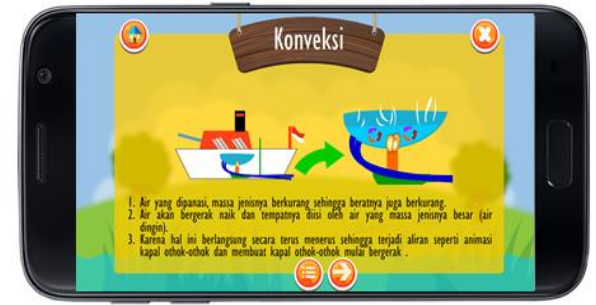

Figure 4. b.

Page Appearance of Heat Transfer Animation

The SMA physics learning media product is in the form of an application in an Android device (such as Smartphone, a tablet,or a notebook). The output of the program was a file with an apk extension which is required for installation in Android.

The matrix which serves as a guideline for the development of the learning media was synthesized from several articles and then described based on the indicators of the diagrammatic and argumentative representation as seen in Table2.

After the learning media was developed, its feasibility was tested by experts and physics teachers. After it was declared feasible, the product was the tested in schools.

The developed learning media was designed to improve the ability of diagrammatic and argumentatitive representation. The content of the material relates to Newton's law. The discussion material used was othok-othok ship, which is a local culture.In line with the research by Isman (2007), the use of technology could improve learners' understanding of concepts of science.Local wisdom that is inserted into the learning process can improve the quality of physics learning. It then becomes meaningful for learners. In addition, active learning which is based on local wisdom contributes to improving student learning outcomes (Brown, 1989; Damayanti, Dewi, \& Akhlis, 2013; Wijayanthi, Lasmawan, \& Natajaya, 2014).

The field testing was conducted to know the feasibility of the learning media. The increase in the diagrammatic and argumentative representation competence could be seen from the differences in scores before and after the learning process. In summary, the mean and mean gain scores obtained are presented in Table 3. 
Table 3

Increase in Diagrammatic and Argumentative Representation Competence

\begin{tabular}{llllll}
\hline Representation & Class & Score & & Mean Gain Score & Category \\
\hline \multirow{2}{*}{ Diagrammatic } & & Pretest & Posttest & & \\
\cline { 2 - 6 } & Experimental & 56.39 & 91.94 & 0.82 & High \\
\hline \multirow{2}{*}{ Argumentative } & Extrol & 35.67 & 84.17 & 0.74 & High \\
\cline { 2 - 6 } & Experimental & 29.17 & 80.56 & 0.72 & High \\
\hline
\end{tabular}

In the research concerned here, an analysis was conductobtained on the focus of the influence using learning media to competence in diagrammatic and argumentative representation.Based on theobtaineddata, there was an improvement in learners' conceptual understanding, which could be an impact of a change in learners' competence in diagrammatic and argumentative representation, making them become those who understand the concepts of Newton's law. According to research by Ainsworth (2008), representations types are powerful tools for assisting students in developing complex scientific knowledge.However, these tools need to be handled with great care and have frequent experience in using the tool before one's could use them with maximum effectiveness. Further research by Schnotz and Bannert (2003), it is acknowledged that textual understanding and pictorial understanding are goal-oriented processes of the human cognitive system, in which individual sactively select and process argumentationandinformation with pictures to build mental representations that would apparently be appropriate to meet the presented or anticipated demands.

Objective of the development in the research was to reject Ho and accept Ha. The decision of whether Ho was to be rejected or accepted was made by using MANOVA with Hottelling's Trace effect as basis. According to Table 4,the significance score obtained was 0.000 , which is smaller than 0.05 , and then, Ho was rejected. Therefore, it was concluded that there was difference in increase the learners' diagrammatic and argumentative representation competence between the experimental class(after learning by using the Android-assisted learning media with local wisdom as basis)and the control class (after learning by other means).

Table 4

Results of MANOVA

\begin{tabular}{lllll}
\hline Effect & Significance & $\begin{array}{l}\text { Criteria for } \\
\text { Decision }\end{array}$ & Decision & Conclusion \\
\hline $\begin{array}{l}\text { Hottelling's } \\
\text { Trace }\end{array}$ & 0.000 & sig<0.05 & $\begin{array}{l}\text { Ho } \\
\text { rejected }\end{array}$ & $\begin{array}{l}\text { There is difference in the increase of } \\
\text { learners' diagrammatic and argumentative } \\
\text { representation competence between the } \\
\text { experimental and the control class }\end{array}$ \\
\hline
\end{tabular}


A comparison of test results in relation with the dependent variables between the experimental class and the control class are presented in Figure 5 and 6.

In the research, the influence of the use of the learning media on the diagrammatic representation competence was analysed. The obtained data showed that there was an increase in the learners' conceptual understanding. There is a change in their diagrammatic representation competence that had helped them understand the concepts of the Newton's law. It is in line with the research findings by Liu, Horton, Lee, Kang, Rosenblum, O'Hair, \& Lu,(2015), who mentioned that using media could help problem solving through its diagrammatic representation.

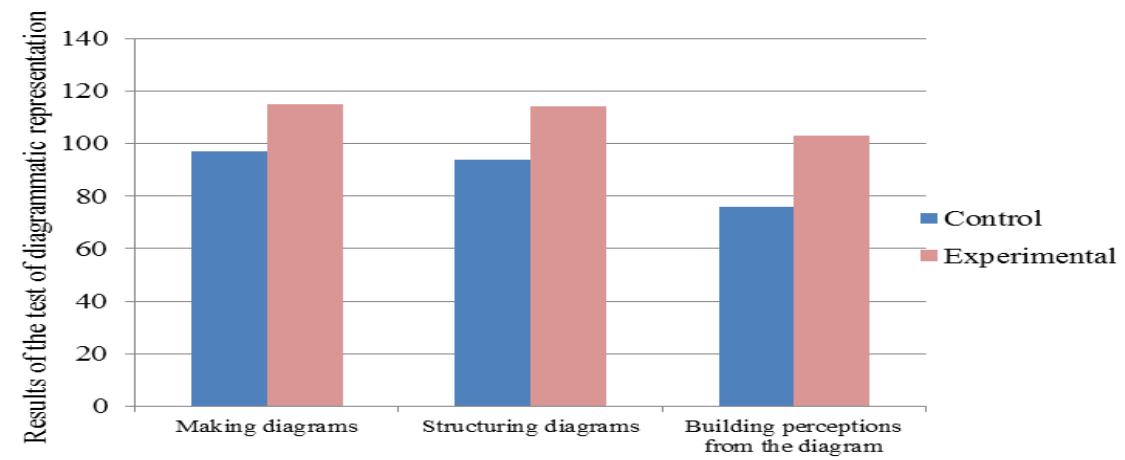

Figure 5

Competence in Diagrammatic Representation

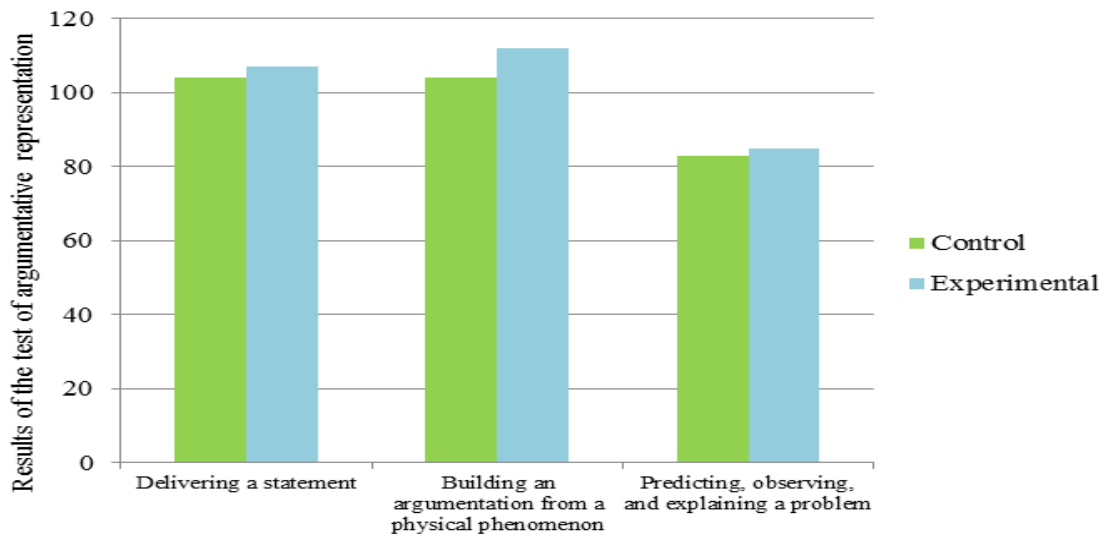

Figure 6

Competence in Argumentative Representation

The increase in argumentative representation competence could be seen from the difference in argumentative representation competence between the experimental and the control class. In summary, the obtained scores for the competence in argumentative 
representation of the two classes, after undergoing learning, different in treatment, are presented in Figure 6.

In the research, the influence of the use of the learning media on argumentative representation competence was analysed. The obtained data showed that there was an increase in the learners' conceptual understanding. It made an impact in their argumentative representation competence which then helped them to understand the concept of Newton's law. However, the difference in score between the experimental and the control class is not significant.According to Simon, Eduran, and Osborne (2006)competence in argumentation is influenced by prior experience. The students in the control class may have been more active in communicating while those in the experimental class may have been more passive in it.Students who can make representations of diagrams generally have better ability to solve problems (Rosengrant et al, 2006; Edens \& Potter, 2008). This is because diagram representation can reduce the complexity of the initial representation and in managing the problem-solving process (Aviani, Erceg \& Mesic, 2015). Whereas argumentation representation is used to guide early knowledge building during learning (Tabachneck-Schijf, Leonardo, \&Simon, 1997). This seems to show that the argumentation representation is useful in connecting the gap in the learning process (Saeki, Saito,\& Kawaguchi, 2006).

From the results of this development suggest that the local culture that are close to the student environment can be used to explain the physics concepts. The ability to be improved should be aligned with the characteristics of cultural products to be used.mproved capabilities are involved when designing media content.

\section{CONCLUSION}

According to the evaluation by experts (or to experts' judgment), material experts, media experts, peer reviewers, and teachers, the developed learning media is feasible to be used in a learning activity as a learning resource. It has received good rating andcould be tested for use in physics learning concerning materials about Newton's law. It could help improve the learners' competence in diagrammatic and argumentative representation at Senior High School.

\section{ACKNOLEDGMENTS}

The research was funded by the Ministry of Research, Technology and Higher Education of the Republic of Indonesia under contract number13/PENEL./P.TIM PASCA SARJANA/UN 34.21/2017. The authors would like to thank the suggestions provided by reviewers of this article.

\section{REFERENCES}

Abildinova, G. M., Alzhanov, A.K,Ospanova, N.N, Taybaldieva, Z., Baigojanova, D.S, \&Pashovkin N.O.(2016). Developing A Mobile Application "Education Process Remote Management System" on the Android Operating System,International Journal of Environmental and Science Education 11 (12), 5128-5145. 
Ainsworth, S. (2008).The Educational Value of Multiple-Representations When Learning Complex Scientific Concepts.In Gilbert, JK, Reiner, M, Nakhleh M, (eds) Visualization: Theory and Practice in Science Education. Models and Modelling in Science Education3 Dordecht: Springer, 191-208.

Ally, M. 2009. Mobile Learning: Transforming the Delivery of Education and Training. Edmonton, Canada: AU Press, Athabasca University.pp.293

Ardan, A.S., Ardi, M., Hala, Y., Supu.A., \& Dirawan, G.D. (2015). Needs Assessment ofthe Development of the Biology Textbook for High School Class X Based on the Local Wisdom of Timor. International Education Studies, 8 (4), 52-59.

Aviani, I., Erceg, N., \&Mešić, V. (2015). Drawing and Using Free Body Diagrams: Why It May Be Better Not To Decompose Forces. Physical Review Special TopicsPhysics Education Research, 11 (2) 020137.

Aviani, I., Erceg, N., \& Mešić, V. (2015). Drawing and using free body diagrams: Why it may be better not to decompose forces. Physical Review Special Topics-Physics Education Research, 11(2), 1-14.

Azizahwati, Maaruf, Z., Yassin, R., Yuliani, M.2015).Development of Physics High School Learning Module Based on Local Wisdom to Improve Student LearningProceedingsat Pertemuan Ilmiah XXIX HFI Jateng \& DIY, Yogyakarta, 70-73

Baynes, R., \&Austin, J. (2012).Indigenous Knowledge in the Australian National Curriculum for Science: from Conjecture to Classroom Practice. Paper Presented at the $5^{\text {th }}$ Biennial International Indigenous Development Research Conference. Auckland: New Zealand.

Brown. J. S., Collins. A.,\& Duguid, P. 1998. Situated Cognition and the Culture of Learning. Calivornia: Education Researcher.

Calimag, J. N., Mugel, P. A., Conde, R. S., \&Aquino, L. B. (2014). Ubiquitous Learning Environment Using Android Mobile Application.International Journal of Research in Engineering \& Technology, 2(2), 119-128.

Chang, C. S., Chen, T. S., \&Hsu, W. H. (2011).The Study on Integrating WebQuest with Mobile Learning for Environmental Education. Computers \& Education, 57(1), 1228-1239.

Choiriyah, R. (2015). Designing Popular book of Cook and Games Era '80'an as a Cultural Identity. Jurnal Desain.1(2), 126-141.

Damayanti, C., Dewi, N., \& Akhlis, I. (2013).Pengembangan CD Pembelajaran berbasis kearifan lokal tema getaran dan gelombang untuk peserta didik SMP kelas VIII.Unnes Science Educational Journal. 2(2), 274-281.

Docktor, J. L., \&Mestre, J. P. (2014).Synthesis of Discipline-Based Education Research in Physics.Physical Review Special Topics-Physics Education Research.10(2), 1-58 
Edens, K., \& Potter, E. (2008). How Students "Unpack" the Structure of a Word Problem: Graphic Representations and Problem Solving. School Science and Mathematics, 108(5), 184-196.

Gandhewar, N., \&Sheikh, R. (2010). Google Android: An Emerging Software Platform for Mobile Devices. International Journal on Computer Science and Engineering, 1(1), 12-17.

Geertz, C. (1992). Kebudayaan dan Agama.Yogyakarta: Kanisius Press

Gonzalez, M.A., da Silva, J.B. D., Canedo, J.C., Huete. F., Esteban. D., Manso. J., Rochadel. W., \& Gonzalez.M.A. (2015). Doing Physics Experiments and Learning with Smartphones. In Proceedings of the $3^{\text {rd }}$ International Conference on Technological Ecosystems for Enhancing Multiculturality. Vol 5, 303-310.

Hanafi, H., \&Samsudin, K. (2015). Mobile Learning Environment System (MLES): The Case of Android-Based Learning Application on Undergraduates Learning. International Journal of Advanced Computer Science and Application.3, 1-5

Huet, J. M., \& Tcheng, H. (2010). What If Telecoms-Were the Key to the Third Industrial Revolution?Paris: Pearson Education.

Holbrow, C.H., Lloyd, J.N., Amato, J. C., Galvez, E., \& Parks, M. E. (2010).Modern Introductory Physics ( $2^{\text {nd }}$ Ed.). New York: Springer.

Hwang, W.Y., Chen, N.S., Dung, J. J., \&Yang, Y.L. (2007).Multiple Representation Skills and Creativity Effects on Mathematical Problem Solving Using a Multimedia Whiteboard System.Educational Technology \& Society, 10(2), 191-212.

Isman.A, Yaratan.H, \& Caner, H. (2007). How Technology is Integratedinto Science Education in a Developing Country: North Cyprus Case. Turkish Online Journal of educational Technology.Vol 6(3), 1-7.

Jengathe, G, Dinesh V, \&Rojatkar.(2015). Use of Android in the Educational System.International Journal of Electronics Research.3(4), 133-137.

Kayalar, F.(2016).Cross-Cultural Comparison of Teachers' Views upon Integration and Use of Technology in Classroom.Turkish Online Journal of educational Technology. 15 (2), 11-19.

Keane. T, Keane.W,\& Blicblau. A. S. (2014). Beyond Traditional Literacy:Learning and Transformative Practices Using ICT. Education and Information Technologies. 21 (4), 769-781

Leetian, N.R.C., Estuar, M.R.E., \&Syson, M.B. (2013).Designing Mobile Educational Games on Voters' Education: A Tale of Three Engines. International Journal of $e$ Education, e-Business, e-Management and e-Learning, 3(5), 357-364.

Liu. M, Horton. L, Lee. J, Kang. J, Rosenblum. J, O’Hair. M,\& Lu. C.W.(2015).Creating a Multimedia Enhanced Problem-Based Learning Environment for Middle School Science: Voices from the Developers. Interdisciplinary Journal of 
Problem-Based Learning. 8 (1), 81-91.

Ma, L., Gu, L., \&Wang, J. (2014). Research and Development of Mobile Application for the Android Platform.International Journal of Multimedia and Ubiquitous Engineering, 9(4), 187-98.

Alqahtani, M, \& Mohammad, H. (2015).Mobile Application Impact on Student Performance and Satisfaction.Turkish Online Journal of Education Technology. 14 (4), $102-112$.

McBride, D. M., \& Cutting, J. C. (2015). Cognitive Psychology: Theory, Process, and Methodology. Los Angles: SAGE Publications.

Meister, J., Kaganer, E., \&Von Feldt, R. (2011).The Year of the Media Tablet as a Learning Tool.Training and Development,65(4), 28-31.

Mungmachon, M, R. (2012). Knowledge and Local Wisdom: Community Treasure.International Journal of Humanities and Social Science.2(13).174-181

Nieminen, P., Savinainen, A., \& Viiri, J. (2012).Relations between Representational Consistency, Conceptual Understanding of the Force Concept, and Scientific Reasoning.Physical Review Special Topics-Physics Education Research, 8(1), 15549178.

Ornek, F., Robinson, W. R., \&Haugan, M. P. (2008.)What Makes Physics Difficult: nternational Journal of Environment and Sciences Education, 3 (1), 30-34.

Parmin, S, Ashadi, S \& Marette, Y. (2016).Preparing Prospective Teachers in Integrating Science and Local Wisdom through Practicing Open Inquiry.Journal of Turkish Science Education, 13 (2), 3-14.

Raghavan, K, \& Glaser, R. (1995). Model-Based Analysis and Reasoning in Science: The MARS Curriculum. Science Education.79 (1), 37-61

Roselli, R. J., Howard, L, \& Brophy, S. (2006). A Computer-Based Free Body Diagram Assistant.Journal Computer Applications in Engineering Education, 14 (4), 281-290.

Rosengrant, D., Van Heuvelen, A., \& Etkina, E. (2006, February). Case study: Students' use of multiple representations in problem solving. In P. Heron, L. McCullough, \& J. Marx (Eds.), AIP Conference Proceedings.818 (1), 49-52.

Saeki, E., Saito, S., \& Kawaguchi, J. (2006).Effect of Response-Stimulus Interval Manipulation and Articulatory Suppression on Task Switching.Memory.14, 965-976

Salkind, G. M., \& Hjalmarson, M. (2007).Mathematical representation. Running head: Mathematical Representations. Preparation and Professional Development of Mathematics Teachers: George Mason University.

Sarrab, M., Elgamel, L., \&Aldabbas, H. (2012).Mobile Learning (M-learning) and Educational Environments.International Journal of Distributed and Parallel Systems, 3, $31-38$. 
Schnotz, W,\& Bannert, M. (2003). Construction and Interference in Learning from Multiple Representation.Journal of Elsevier. 13, 141-156

Schworm, S., \&Renkl, A. (2007).Learning Argumentation Skills Through the Use of Prompts for Self-Explaining Examples.Journal of Educational Psychology, 99(2), 285296.

Simon, S., Erduran, S., \& Osborne, J. (2006).Learning to teach argumentation: Research and development in the science classroom. International Journal of Science Education, Vol.28, 235-260.

Steif, P. S., \& Dantzler, J. A. (2005). A statics concept inventory: Development and psychometric analysis. Journal of Engineering Education, 94(4), 363-371.

Squire, K. D., MaKinster, J. G., Barnett, M., Luehmann A. L., Barab, L. S. (2003).Designed Curriculum and Local, Culture: Acknowledging the Primacy of Classroom Culture. Journal of Education Psichology.87 (4), 468-489.

Tabachneck-Schijf, H. J., Leonardo, A. M., \& Simon, H. A. (1997). CaMeRa: A computational model of multiple representations. Cognitive Science, Vol. 21(3), 305350 .

Thiagarajan, S., Semmel, D.S.,\&Semmel, M.I. (1974).Intructional Development for Training Teachers of Exceptional Children. Indiana: Indiana University Bloomington.

Waldrip, B., Prain, V., \& Carolan, J. (2006).Learning junior secondary science through multi-modal representations. Electronic Journal of Science Education, 11(1), 87-106.

Wang, G., Sun, J., Ma, J., Xu, K., \&Gu, J. (2014). Sentiment Classification: The Contribution of Ensemble Learning. Journal of Decision Support Systems, 57, 77-93.

Wijayanthi, A. A. S. O. V., Lasmawan, I. W., \& Natajaya, I. N. (2014). Pengaruh Model Pembelajaran Inkuiri Terbimbing Berbasis Kearifan Lokal Terhadap Tanggung Jawab Dan Hasil Belajar Ips Siswa Kelas V Sd Gugus I Gusti Ngurah Rai Denpasar Selatan. Jurnal Pendidikan Dasar, 4(1), 1-8.

Wong, W.K., Xu, J.M., \&Chao, T.K. (2011).Using Android Mobile Devices for Physics Experiments and Inquiry.In International Conference on Computers in Education. 11,13.

Yektyastuti, R., \& Ikhsan, J. (2016).Pengembangan Media Pembelajaran Berbasis Android pada Materi Kelarutan untuk Meningkatkan Performa Akademik Peserta Didik SMA.Jurnal Inovasi Pendidikan IPA, 2 (1), 88-99. 